\title{
Музейный экфрасис в русской прозе XX века
}

\author{
М. В. БИРЮКОВА \\ Marina BIRYUKOVA, Кафедра музейного дела и охраны памятников, Санкт-Петербургский \\ государственный университет, Менделеевская линия, д. 5, RU-199034 Санкт-Петербург \\ E-mail: arsvita@mail.ru
}

(Received: 27 October 2016; accepted: 19 January 2017)

\begin{abstract}
This paper offers an analysis of museum ekphrasis as a subgenre of ekphrasis, understood in literary studies as a description and interpretation of works of art in poetry and prose. Previously, the concept of museum ekphrasis has not been considered by researchers as the definition of an independent genre, while description of museum exposition and museum exhibits not only had been significantly represented in literature but often had the quality of hypertext. The author analyzes museum ekphrasis in the texts of A. Bitov, Y. Dombrowski, S. Dovlatov, A. Ivanov, K. Vaginov, and contemporary authors, where museum discourse is not limited to the description of real and imaginary museums but the museum represents the metaphysical projection of reality, or hypertext, symbolically associated with the cultural paradigm of the era.
\end{abstract}

Keywords: museum ekphrasis, 20th-century Russian prose, museum, text

\section{Репрезентация музея в экфрастическом описании}

Проблема экфрасиса, понимаемого как «жанр словесного представления... произведений изобразительного искусства» (ГЕЛлЕР 2013: 45) или «вербальная репрезентация визуальной репрезентации» (HEFFERNAN 2004: 3 ) в последнее время привлекает научный интерес в контексте междисциплинарных исследований в сфере взаимодействия литературы и визуального творчества (Barbetty 2011, Cheeke 2010, Геллер 1997, Krieger 1992, LoizeauX 1999, SHAFFER 1998, WEBв 1999). Экфрасис в традиционном понимании, отсылающем к античным описаниям произведений искусства, например, у Гомера и Филострата, касается по преимуществу литературной интерпретации визуальных искусств, реже - архитектуры и музыки.

Существует ряд интереснейших трудов, посвященных проблеме экфрасиса как описания произведений искусства и художественного творчества в литературе, и, в том числе, экфрасиса в русской прозе и поэзии ХІХ и ХX вв. (БочКАРеВА 2014, ГеЛЛЕР 2002, КРИВОРУчко 2008, МоРОзОВА 2006, РуБИНС 2003).

В то же время, экфрасис музея или описание и интерпретация музейной экспозиции как самостоятельная разновидность экфрасиса пока не получил освещения в научной литературе. Принимая во внимание значительность репрезентации музейного образа, в частности, в русской прозе XX века - в произведениях К. Вагинова, Ю. Домбровского, С. Довлатова, А. Битова, тема 
музейного экфрасиса, безусловно, может быть выделена в качестве самостоятельной научной проблемы. По нашему мнению, музейный экфрасис не исчерпывается только образным описанием музейной экспозиции, но может рассматриваться в качестве гипертекста, содержащего символико-аллегорический смысл и коннотации, тесно связанные с культурной парадигмой определенной эпохи. Например, в рассматриваемой далее повести А. П. Иванова «Стереоскоп», написанной в начале XX в., образ классического музея несет определенные черты модернистского представления об «уходящей», «прошлой» культуре, а в романе А. Битова «Пушкинский дом» разгром в музее ассоциируется с постмодернистской деконструкцией текста.

\section{Символика музея в литературе периода модернизма: «Стереоскоп» А. П. Иванова}

В 1909 г. был опубликован «Стереоскоп» искусствоведа А. П. Иванова, будущего сотрудника Русского музея. Герой этого «сумеречного рассказа», как его представил автор, приобретает на антикварном складе подержанный стереоскоп и обнаруживает там снимок зала Юпитера в Новом Эрмитаже. Пристально разглядывая снимок, герой чудесным образом переносится почти на два десятилетия в прошлое и оказывается в «фотографическом» Эрмитаже. Только этот Эрмитаж, в отличие от реального, окрашен в бурые, потускневшие тона старой фотографии, а редкие посетители выглядят неживыми, за исключением старухи-«фантоши», которая преследует протагониста по залам «минувшего» Эрмитажа. И от экспонатов, и от знакомых залов веет мертвенностью, застылостью и заброшенностью. Автор «сумеречного рассказа» многократно использует в описании музея эпитеты, указывающие на качества безжизненности и ненужности: «минувший», «бывший», «застывший», «мертвый», «выцветший» и т. д. В экфрасисе Египетского зала, например, преобладает впечатление мертвенности и призрачности:

Вот глянул мне навстречу Египетский зал, глубоко знакомый и вместе чуждый в своей здешней призрачности. Он и настоящий беден живыми красками и светом; здесь же обступил он меня выцветший до конца, буроватый, тонущий в мертвенной мгле. Он был без конца безмолвен; был страшен и влекущ. В таинственном сумраке прислонялись к стенам ассирийские барельефы; из стеклянных футляров глядели исполины, запеленутые, с грозно-веселыми и загадочными лицами; мрачными рядами стояли саркофаги. [...] Я простоял неподвижно несколько минут, слушая мертвую тишину давно прошедшего (ИвАнов 2003: 10).

Безусловно, подобное описание классического музея близко современной А. Иванову риторике модернизма, прокламирующей отказ от старого, «мертвого» искусства и призывающей к созданию новых метафизических ценностей на руинах «бывшей» культуры. Не случайно появление в это время настойчивых сравнений классического музея с «гробом», «кладбищем» 
искусства, которое лучше сравнять с землей, чтобы освободить пространство для новаторских течений. Например, К. Малевич писал: «Нужно поступить со старым - больше чем навсегда похоронить его на кладбище» (МАЛЕВич 1919: 28). И далее: «Перед нами стоит задача выровнять гроб уродливого отношения старого к новому, разбить до конца авторитетные лики, разогнать всех старьевщиков, чтобы не мешали нашей ,дерзости“ поставить на пьедестал ковку нового нашего образа» (МАлевич 1919: 28).

В повести А. Иванова явственно ощущается динамика этого радикального, разрушительного отношения к музею. В деструктивном порыве и сам герой зачем-то разбивает витрину с египетскими древностями и похищает старинного скарабея, а в конце повести ломает и чудесный стереоскоп, чтобы избежать соблазна вновь и вновь возвращаться в залы «прошлого» Эрмитажа. В целом же ненужность, ретроградность музея особенно проявляется в сопоставлении с аукционным складом, по сути подобным музею, где герой купил стереоскоп. Вот своеобразный музейный экфрасис в духе модернизма, но, на этот раз, относящийся к складу:

Мне нравилось смотреть на этот хлам, на эти груды утвари по большей части старомодной, давно вышедшей из употребления. Это были все старые вещи, попавшие теперь в Склад, но когда-то кому-то принадлежавшие; жизнь минувших людей, когда-то окружавшая их, словно впиталась в них и веяла на меня теперь тихим и грустным дуновением. [...] Странной формы подсвечники, старинные лампы, чернильницы, поношенные бинокли и зрительные трубы; даже остов огромного морского рака в стеклянном футляре, причудливый, побелевший от времени и никому не нужный (ИвАнов 2003: 6).

Описание музея как «склада ненужных вещей» и «царства мертвых» в «Стереоскопе» является модернистским ответом на попытки сохранить достижения прошлой культуры, предпринимаемые на рубеже XIX-XX вв. апологетами традиции, например, философом Н. Ф. Федоровым, изложившим свою концепцию музея в статье «Музей, его смысл и назначение». Основная идея Н. Федорова - идея «патрификации», то есть сохранения памяти предков, их воображаемой реинкарнации, и музей, «последний остаток культа предков», в его представлении служит этой цели: это «высшая инстанция, которая должна и может возвращать жизнь» (ФЕдоРов 1913: 399). Музей - живой, и служит для возрождения жизни, в то время как у А. П. Иванова он определенно отжил свое. Н. Федоров тоже не избегает сравнения музея с кладбищем, но у него это сопоставление звучит не уничижительно, а гордо: «Музей и выше, и ниже кладбища; если бы братство не было целью музея, то касаться праха умерших было бы святотатством» (ФЕдоРов 1913: 401).

Концепция музея Н. Федорова заключает в себе возможность примирения современного человека и прошлого, современности и традиции, разрыв которых был столь обнажен и болезнен в риторике модернистов. У А. Иванова такого примирения не происходит: в «Стереоскопе» фантомы «мертвого» Эрмитажа абсолютно враждебны протагонисту, они преследуют и пугают 
его, не оставляя возможности для взаимопонимания. У Иванова «прошлое» и ассоциация с прошлым имеет оттенок погружения в ад, в преисподнюю, где нет места ничему светлому и возвышенному. Модернистское представление о музее в тексте Иванова антагонистично концепции музея апологета традиции Н. Ф. Федорова. Тем не менее, в его тексте явственны символические связи музея и культуры модернизма, основанные на обостренном ощущении категории времени, переживании идеи смерти и представлениях о музее, связанных с диалектикой «подлинного» и «ложного».

\section{Гипотетические музеи в романах Константина Вагинова}

Апофеоз музейной темы - помещение частной коллекции в музей становится сознательной или бессознательной интенцией героев романов К. Вагинова «Козлиная песнь», «Бамбочада», «Гарпагониада». Собиратель всякой ерунды вроде конфетных оберток и открыток Костя Ротиков грезит о том, что его коллекцию китча с почетом примут в Эрмитаж, а стоматолог Миша Котиков мечтает пристроить собранные им биографические сведения о поэте Заэвфратском в «Тихое убежище», то есть в Пушкинский дом. Котиков собирает сведения об умершем поэте, прототипом которого, по-видимому, был Н. Гумилев, но его деятельность псевдонаучна и состоит, в основном, в сборе сплетен и попытках сблизиться с бывшими любовницами поэта. Котиков копирует почерк Заэвфратского и строчит поддельные стихи, планируя приобщить их к наследию поэта. Квазиэкфрастическое описание материалов будущего музейного фонда, посвященного Заэвфратскому, звучит сомнительно:

1917 г. Зима. Вечером, перед отъездом (куда - неизвестно), час неизвестен. Связь с маникюршей Александрой Леонтьевной Птичкиной. Птичкина говорит, что она никаких подробностей не помнит. Глупая, необразованная натура. Говорит, что А. П. был как все мужчины.

Но тут Михаил Петрович посмотрел на часы.

- Какое весеннее утро. Подумать только, что я вызываю из небытия жизнь Александра Петровича (ВАгинов 2008: 126).

Карикатурная биография, пародийная копия жизнеописания поэта, состоящего у Котикова из маргинальных, пустых и подтасованных фактов, пусть и педантично классифицированных, предполагает помещение в столь же легкомысленно организованное музейное хранение.

Интенции чудаков-собирателей у Вагинова предвосхищают начало музейного бума второй половины ХХ века, когда появилось множество музеев с сомнительным и маргинальным контентом, как, например, Музей плохого искусства в Бостоне. Характерно и появление во второй половине XX века концепций гипотетических музеев: «Музей мышей» художника Клэса Олденбурга, «воображаемый музей» А. Мальро, музеи-концепции кураторов: 
«Анти-музей» Й. Кладдерса, «Музей обсессий» Х. Зеемана. Константин Вагинов, сам увлекавшийся, как и его герои, коллекционированием книг и купленных на рынке безделушек, предчувствовал эту тенденцию оформления частных, внешне бессмысленных представлений об искусстве и коллекционировании в квазимузейную концепцию.

Экфрасис гипотетических музеев героев-чудаков в текстах Константина Вагинова разнообразен и прихотлив. В романе «Гарпагониада» преподаватель Жулонбин, он же «систематизатор» буквально одержим манией коллекционирования: он собирает все подряд, включая молочные зубы и ногти своей малолетней дочки, которые он «систематизирует» и складывает в коробочки с этикетками. Коллекция Жулонбина поражает избыточностью и бессмысленностью:

В шкапу хранились бумажки, исписанные и неисписанные, фигурные бутылки из-под вина (некоторые из них должны были изображать великих поэтов, писателей, деятелей науки, политики), высохшие лекарства с двуглавыми орлами, сухие листья, засушенные цветы, жуки, покрытые паучками, бабочки, пожираемые молью, свадебные билеты... даже орден черепахи за рабские темпы ликвидации неграмотности был здесь (ВАгинов 2016).

Перечисление случайных и не связанных между собою предметов коллекции напоминает описание аукционного склада в «Стереоскопе» А. Иванова, и, в то же время, коллекцию гипотетического музея ненужных вещей. Своей манией собирательства Жулонбин заражает даже маленькую дочку, которая, в свою очередь, собирает ногти и зубы своих подруг, ловит мух, подбирает в школе огрызки карандашей, фантики, черновики классных работ, чтобы пополнить папину коллекцию. Знакомые Жулонбина тоже собирают разные вещи:

Бухгалтер Клейн, например, копил все с изображением Петербурга, от открыток до пивных этикеток. Престарелый Дон-Жуан, режиссер небольшого театрика - свистульки, киноактер - дамские перчатки. Были собиратели обрывков кружев, кусочков парчи, бисеринок, дамской отделки (ВАгинов 2016).

Персонажи «Бамбочады» и «Гарпагониады» Торопуло и Пуншевич основывают «Общество собирания и изучения мелочей» повседневного быта. Некоторые герои Вагинова поднимаются на более высокий уровень навязчивой обсессии коллекционирования: собирают не только вещи, но впечатления, как «биограф» Заэвфратского Котиков, или даже сновидения, как герой «Гарпагониады» Локонов.

Квазимузейный экфрасис у Константина Вагинова своеобразно предвосхищает появление новых послевоенных течений искусства XX века, например, концептуализма, большинство объектов которого, не имеющих традиционной художественной формы, можно хранить в музее разве что в виде документации. 


\section{Музей как советская институция}

Пугающий образ советского музея в эпоху сталинизма создан Юрием Домбровским в дилогии «Хранитель древностей» (1964) и «Факультет ненужных вещей» (1978). История протагониста романов Георгия Зыбина, хранителя археологических древностей, служащего в Алма-Атинском музее, во многом повторяет историю самого Домбровского, высланного в Алма-Ату после ареста в 1932 году. Во втором романе дилогии «Факультет ненужных вещей» творчески переработаны подробности второго ареста автора: его героя обвиняют в присвоении драгоценного клада, на самом деле похищенного рабочими. По счастливой случайности, клад был найден, а молодой археолог отпущен на свободу, несмотря на клевету интриганов-коллег и старания следователей НКВД. Дальнейшая судьба самого Юрия Домбровского была более трагична, чем судьба его героя: писатель был вновь арестован и отправлен в лагерь на Колыму в 1939 году, затем освобожден, но в 1949 году опять арестован и реабилитирован только в 1956 году.

Но остановимся более подробно на интересующей нас теме музейного экфрасиса. Протагонист романа «Хранитель древностей» поступает на работу в краеведческий «Музей республики» в Алма-Ате, находящийся в помещении церкви. В буквальном смысле слова «сакральное место», что столь часто является характеристикой музея, не было, тем не менее, воплощением святости. Описание разнообразных черепов и костей животных, хранящихся без всякой системы на чердаке музея, производит впечатление не музейной коллекции, а покинутого побоища с заброшенными, не удостоенными должного захоронения останками.

А под ногами черепа - целая верещагинская пирамида черепов. Сколько их тут было! Черепа длинные и круглые, черепа клыкастые и совсем беззубые, черепа рогатые и безрогие, черепа птичьи и звериные, черепа на полу, в фанерных ящиках, на балках и прямо под ногами. И кто только не сложил тут свою вольную голову! Рядами лежали архары с узорчатыми зубами, поодаль от них тигры с коварными, по-кошачьи узкими и косыми глазницами, в углу - волки (ДомьРовский 2011: 32).

Сравнение этого зрелища с батальными полотнами Верещагина и упоминание, что здесь «сложили вольные головы», будят непосредственную ассоциацию с полем боя, а обладатели костей наделяются антропоморфными чертами, что придает дополнительную остроту переживаниям читателя по поводу неприкаянности их останков. Атмосфера беспорядка и бестолковости возникает при первом же описании музея: молодая сотрудница предлагает герою, не имеющему ни малейших навыков в реставрации, склеить из разбитых черепков караханидской керамики XI в. «хотя бы с десяток сосудов». Началом деятельности героя в музее стала попытка привести в порядок коллекцию черепов. Но «классификация» была примитивной, вне времени, вне географического положения, просто «волк к волку, тигр к тигру, кабан к кабану». 
От этой работы на посту «хранителя древностей» веяло дилетантизмом и беспечностью, отражавшими самую суть работы в этом советском музее.

Следом за черепами протагонист начинает сортировать «камни» и предметы из металла. С привычным уже легкомыслием герой распределяет артефакты по коробкам вне зависимости от стилей и эпох:

Щиты - в одно место, ящики с камнями - в другое, бронза и монеты (монеты лежали в сумках) - от екатерининских пятаков до римских динариев и серебристых чешуек с арабскими надписями - в третье и четвертое (ДомьРовский 2011: 119).

Тут он обнаруживает, что коллекция ранее подвергалась исследованию очень знающих, судя по разрозненным записям, специалистов, в частности, некого Кастанье:

«Из сборов Кастанье», «Из коллекции Кастанье», «Описано Кастанье», «Смотри рисунок в монографии Кастанье». [...] Сколько он насобирал камней! И там Кастанье, и тут Кастанье, и везде один и тот же Иосиф Антонович Кастанье «ученый секретарь Оренбургской архивной комиссии» (ДомБРОвский 2011: 119).

Однако, с сожалением признается протагонист,

этими титулами, пожалуй, исчерпывается и все, что я о нем знаю. Да только ли я один? И никто ничего не знал о Кастанье. [...] Так я и не знаю, когда он родился, когда умер и даже какая цена его книгам. Знаю только, что был он подвижен и энергичен необычайно (ДомБРовский 2011: 122).

Эта лаконичная фраза, абсурдно подводящая итог деятельности ученого, свидетельствует лишь об одном - об окончательном и бесповоротном отрыве от традиции.

Впечатление ненужности и бессмысленности музейных экспонатов и музейной деятельности возникает на протяжении всего романа. Артефакты либо утилитарно служат сотрудникам: на них сидят, в них хранят семечки и прочие, либо мешают им: герой жалуется, что из-за больших экспонатов в его кабинете тесно. При таких обстоятельствах одна из основных музейных функций - приобретение и собирание объектов становится бессмысленной. Протагонист вспоминает, что однажды к нему пришел старик, поведавший, что в колхозе в горах на земле полно осколков древних сосудов. Но, записав рассказ старика, герой признается, что

никуда не поехал и ничего никому не сообщил. Я и свои корчаги давно выбросил бы на помойку, - да как это сделать? Ведь на каждой же этикетка и запись: «Сосуд для хранения зерна. Эпоха караханидов (XI век). Из сборов И. А. Кастанье» (ДомьРовский 2011: 122).

В «Хранителе древностей» Ю. Домбровский рисует пугающую картину антимузея, избавляющегося от своих основных функций собирательства, 
классификации и исследования, каким становится советский провинциальный музей в его худшем воплощении - с безразличными хранителями и отсутствием преемственности традиции. Если у Иванова «бывшие», «ненужные» музейные предметы - это умозрительная категория, всего лишь иной взгляд на музей в свете новых идей модернизма, то заброшенная в беспорядке коллекция в «Хранителе древностей» вызывает жалость: это прямое, непосредственное уничтожение артефактов, «ненужных» уже не метафизически, но жизненно, онтологически. В окружении, где человеческая жизнь ничего не стоит, где предательство коллег и близких людей - обычная ситуация, уже не до музейных экспонатов.

Менее жесткая и негуманная онтологическая модель советского музея показана в «Заповеднике» (1977-1978, закончен в Нью-Йорке в 1983 году) Сергея Довлатова, где представлена уже иная эпоха - эпоха «застоя», не столь страшная, как эпоха сталинизма. Тем не менее, ощущение несвободы и тесно связанного с ней общественного лицемерия и ханжества довлеет над текстом. Чудесное место, музейно-парковый комплекс в Псковской области, посвященный памяти самого любимого в России поэта, отбывавшего ссылку в этих местах, лишается в описании Довлатова своей сакральной притягательности. Главным героем здесь является Борис Алиханов, тот же персонаж, что и герой довлатовской «Зоны». Как и сам Довлатов, герой «Зоны» служит надзирателем в колонии для преступников, а в «Заповеднике» поступает на место экскурсовода. Андрей Арьев в послесловии к «Заповеднику» отмечает, что протагонист может ассоциироваться не только с самим Довлатовым, но и с Иосифом Бродским, в свое время безуспешно пытавшимся устроиться в заповедник хотя бы на место библиотекаря. Музей-заповедник порой воспринимается как аналог лагеря. В тексте в описании комплекса присутствуют параллели с описанием тюремной зоны. Даже в организации экскурсий по пушкинским местам есть элементы насилия над здравым смыслом и свободным выражением отношения к Пушкину:

- Экспозицию знаете? - спросила блондинка и неожиданно представилась: - Галина Александровна.

- Я был здесь раза три.

- Этого мало.

- Согласен. Вот и приехал снова...

- Нужно как следует подготовиться. Проштудировать методичку. В жизни Пушкина еще так много неисследованного... Кое-что изменилось с прошлого года...

- В жизни Пушкина? - удивился я (ДовлАтов 1991: 273).

Чтение научной литературы не слишком обогащает содержание экскурсий. В музейных залах звучат шаблонные фразы:

Вдумайтесь, товарищи!.. «Я вас любил так искренне, так нежно...». Миру крепостнических отношений противопоставил Александр Сергеевич этот вдохновенный гимн бескорыстия (ДовлАТОВ 1991: 273). 
Диалектика бытия (и текста), тем не менее, требует резкой реакции на всеобщее лицемерие и «квазитюремные» порядки. Выражается такая реакция в поистине скотском и хамском отношении экскурсоводов к памяти поэта, прорывающемся в моменты «бессознательного», то есть, по преимуществу, когда персонажи находятся в подпитии. Пьяный гид Митрофанов выражает подобные интенции нечленораздельно (он был ужален в язык пчелой, поэтому, по аналогии с известным стихотворением А. С. Пушкина, играет здесь своеобразную роль юродствующего псевдопророка):

- Что? - спросила моя жена.

- Ы-ы-а, - повторил Митрофанов.

- Он говорит - «фикция», - разьяснил Потоцкий. - Он хочет сказать, что аллея Керн - это выдумка Гейченко [С. С. Гейченко, организатор музейно-паркового комплекса - М. Б.]. То есть, аллея, конечно, имеется. Обыкновенная липовая аллея. А Керн тут ни при чем. Может, она и близко к этой аллее не подходила.

- А мне нравится думать, что именно там Пушкин объяснился с этой женщиной.

- Она была куртизанкой, - сурово уточнил Потоцкий.

- Фо-фо ху-ха, - добавил Митрофанов.

- Володя хочет сказать - «просто шлюха». И, грубо выражаясь, он прав. Анна Петровна имела десятки любовников. Один товарищ Глинка чего стоит... А Никитенко? И вообще, путаться с цензором - это уже чересчур! (ДовлАтов 1991: 321).

В духе М. Бахтина, в душной атмосфере закосневшего культа великого поэта неожиданно проявляются неуместные формы ерничанья и скабрезного шутовства, совершенно в традиции средневекового «праздника дураков». По М. Бахтину, «почти все обряды праздника дураков являются гротескными снижениями различных церковных обрядов и символов путем перевода их в материально-телесный план» (БАХтин 1990: 11). В вышеприведенном «экфрастическом разговоре» описание одной из ключевых достопримечательностей музейно-паркового комплекса - аллеи Керн вдруг становится поводом для непристойных шуток в адрес одной из главных муз А. С. Пушкина.

В романе раскрываются три степени восприятия пушкинского заповедника: педантично-назидательный в наставлениях служителей музейного комплекса по приезде героя, фривольный - в изложении развязных экскурсоводов во время посиделок в кафе и полностью отстраненный, абсурдистский в сознании мертвецки напившегося протагониста. Метафизическая схема заповедника (в противовес фальши устоявшегося ритуала поклонения поэту) проявляется в, казалось бы, нелепых и абсурдных метаниях героя. Как считает А. Генис, «трагические события „Заповедника“ осветлены болдинским ощущением живительного кризиса. Преодолевая его, Довлатов не решает свои проблемы, а поднимается над ними. Созревая, он повторяет ходы пушкинской мысли. Чтобы примерить на себя пушкинский миф, Довлатов должен был не прочесть, а прожить Пушкина» (Генис 1999). Если следовать 
логике А. Гениса, настоящий музейный экфрасис в романе Довлатова - не в отдающих фальшью описаниях музейных коллекций (где, как сокрушается протагонист, почти нет подлинных, принадлежащих Пушкину вещей), а в перечислении злоключений героя, в запое бредущего по заповеднику. По А. Генису, «ложный» миф заменяется подлинным, когда сам герой переживает основные перипетии пушкинского мифа: сомнения в преданности супруги, долги, кутежи, конфликт с властью.

Довлатовский «Заповедник» возвращает музейную тему в сферу размышлений по поводу подлинного и ложного, сиюминутного и вечного, сакрального и профанного. Достижение серьезности восприятия музейного пушкинского мифа парадоксальным образом становится возможным посредством безжалостной насмешки над этим мифом.

В отличие от бунтарского «Заповедника», образ музея в романе В. А. Солоухина «Письма из Русского музея» (1966) вполне нейтрален и сервилен: это лишенное метафизических аллюзий описание экспонатов, по стилю напоминающее каталог или путеводитель. Сам автор ссылается на известные «Образы Италии» П. П. Муратова, как на один из образцов, которым он следовал. Принадлежность этого текста к советской эпохе проявляется в нарочитом дилетантизме и легкой снисходительности в описании дореволюционных музейных артефактов. К примеру, приведя известные стихи Николая Заболоцкого о портрете Струйской Ф. Рокотова, автор отмечает:

Впрочем, Рокотов был превосходный колорист. Именно поэтому так живы до сих пор глаза Струйской. Нет, что ни говорите, разве не интересно встретиться взглядом с Шуваловым, Репниным, Уваровой, какой-нибудь там Новосильцевой, какой-нибудь там Борятинской (кажется, бабушка пленителя Шамиля?), ну и вплоть до императрицы? (Солоухин 1966).

В сравнении с диалектически напряженными текстами Ю. Домбровского и С. Довлатова роман В. Солоухина представляется нейтральным текстом, образцом прозы, которая a priori не может вызвать негативную реакцию у власть предержащих. Это, в своем роде, китчевый текст, который был способен понравиться большинству советских людей.

\section{Образ музея в эпоху постмодернизма. Музей как гипертекст в романе Андрея Битова «Пушкинский дом»}

Если у Сергея Довлатова распорядок пушкинского заповедника подчинен строгим, хотя и не тираническим правилам, регулировавшим бытование культурных институций эпохи «застоя», то в «Пушкинском доме» Андрея Битова, написанном в 1964-1971 гг. и изданном впервые в Нью-Йорке в 1978 году, размеренная повседневная жизнь музея оказывается нарушенной неуправляемыми, поистине постмодернистскими интенциями героя, потерявшего культурные и социальные ориентиры. В романе Битова литературный текст 
и музей - объекты постмодернистской деконструкции, и в то же время - две категории, вступающие между собой в сложные, диалектические отношения.

Как утверждает автор в «Прологе, или Главе, написанной после остальных» (помещенной, тем не менее, в начале романа, задавая тон впоследствии нарастающей инерции деконструкции), это «роман-музей», где любая строчка, как и любой артефакт, может стать объектом пристального внимания читателя, где каждый «клочок газеты, раз уж не пошел по назначению, мог быть вставлен в любую точку романа, послужив естественным продолжением и никак не нарушив повествования» (Битов 1990: 8). Драматургия повествования основывается на личных переживаниях героя - филолога Левы Одоевцева, сотрудника Пушкинского дома, а ключевая категория в образе музея личная история великого поэта. Разделы и главы романа - одновременно и части экспозиции гипотетического музея, посвященного русской литературе, и вехи личной жизни протагониста. Первый, «тургеневский» раздел «Отцы и дети» - о детстве, об отношениях с родителями, с фамильной историей, с дедом-ученым, сумевшим вернуться в родной город после отсидки в лагерях. Второй, «лермонтовский» раздел «Герой нашего времени» - об увлечениях Левы женщинами, а последний, «пушкинско-достоевский» «Бедный всадник» - с соответствующими главами «Невидимые глазом бесы» и «Утро разоблачения или Медные люди», и опять с апелляцией к Лермонтову в названии главы «Маскарад», а также к Чехову (но одновременно, онтологически - и к Лермонтову, и к Пушкину!) «Дуэль». Продолжая тему заимствований, автор признается:

И название этого романа - краденое. Это же учреждение, а не название для романа! С табличками отделов: «Медный всадник», «Герой нашего времени», «Отцы и дети», «Что делать?» и т. д. по школьной программе... Экскурсия в роман-музей... (Битов 1990: 134).

Переход к теме собственно Пушкинского дома осуществляется от текста - от статьи самого Левы о Пушкине. Дискурс музея здесь плавно переходит в метатекст. Это также «связка», как говорят экскурсоводы. Элементы экскурсии присутствуют и в описании приключений героев в романе-музее.

Как и в обычной музейной экскурсии, ключевой прием повествования повторение, а также наличие разных версий одной и той же сюжетной линии. «Вечное возвращение» - квинтэссенция существования музея. В ином варианте развития событий повторяется история возвращения деда, заново, в главе «Фаина» рассказывается (опустив отрочество) история молодого Левы, уже не с акцентом на семейное прошлое, а на отношения с женщинами и с близким другом Митишатьевым, злым гением и искусителем, с подачи которого позднее происходит разгром музея Пушкинского дома. В конце романа читатель вынужден гадать - умер герой или остался в живых. По словам В. Курицына, в «превращении мертвого музея в живой, закрытого смысла в открытый, завершенности в принципиальную незавершенность Битов преуспел больше своего героя. Во-первых, структура романа принципиально 
разомкнута в самые разные стороны. Пример рассовмещения - история „души“ (первая часть) и история ,,тела“ (вторая часть), два повествования об одном и том же времени, которые ухитряются практически не пересекаться» (Курицын 1996).

Возвращаясь к теме экфрасиса, можно утверждать, что музейное описание у Битова столь же многогранно, и столь же подвержено инерции деконструкции, что и апелляция к произведениям русской литературы. Внутри жанра музейного экфрасиса стихийно формируется поджанр экфрасиса «города-музея», то есть Петербурга-Ленинграда с его наполненными литературными коннотациями памятными местами. Лева Одоевцев

с удивлением поймал себя на соображении, что, пожалуй, во всю жизнь, ни разу не покидал старого города, жил в этом музее, ни один его житейский маршрут не пролегал за пределы музейных же проспектов-коридоров и зал-площадей (Битов 1990: 8).

Но не только петербургские места, но и сами события в «романе-музее» порой воспринимаются как музейные экспонаты, хотя автор и отмечает трудность «экфрасиса»:

Как изображать прошлое, если мы теперь знаем, что, оказывается, тогда происходило - тогда не знали (Битов 1990: 136).

Так, в восприятии Левы, трудно было оценить значение смерти Сталина, о которой идет речь в приведенной выше цитате. К событиям и воспоминаниям трудно подобрать музейную этикетку, нельзя сделать точную атрибуцию, определить провенанс... Сложность интерпретации «экспоната» отмечает Лева, говоря о портрете Сталина, в котором что-то неумолимо изменилось после смерти вождя:

Это странное чувство, что портрет уже не жив, ибо жив был именно портрет, потому что самого-то живого - никто не видел. Леве хочется понять, что исчезло из портрета: ему кажется, что он изменился, хотя, ясно, не мог он измениться за одну ночь (Битов 1990: 137).

Игра, призрачность, «ненастоящесть» - существенные качества событий, предметов и персонажей романа-музея. Постмодернистская неопределенность пронизывает текст, провоцирует героев на необъяснимые с точки зрения здравого смысла поступки. Чтобы придать некую достоверность поведению персонажей, Битов использует известный прием, оправдывающий изменение сознания, переносящий действие в абсурдную, фантасмагорическую сферу: как и у Довлатова, в самые ключевые моменты рассудок героев затуманен алкоголем. В алкоголическом кураже Лева, которому сослуживцы поручили остаться в Пушкинском доме во время праздников, устраивает псевдо-дуэль с Митишатьевым в музее, крушит экспозицию, выбрасывает книги с полок. Митишатьев разбивает посмертную маску Пушкина. Тема 
смерти и бессмертия - одна из ключевых музейных тем. Прошлое живо в экспонатах, но вообще, согласно еще модернистской риторике, в музее «жизни нет». Автор отвечает на это:

В Пушкинском доме и не живут. Один попробовал... (Битов 1990: 253).

В то же время герой стремится оказаться в музее как в месте обетованном. Отлучившись из учреждения на пьяную прогулку с Митишатьевым, Лева, испугавшись милиционера, бежит обратно в Пушкинский дом, от реальности - в музей, от жизни активной - к жизни созерцательной, повторяя извечный путь интеллигента.

Наутро после разгрома Лева с помощниками быстро устраняет следы вандализма, вставляет стекла, заменяет разбитую маску Пушкина на гипсовую копию. Следов торопливого новодела, подделки никто из сотрудников не заметил. Гибель музея в постмодернистском дискурсе - это тоже симулякр. Самое главное событие в бытовании музея совершилось, когда пьяный Лева безответственно вздохнул в него призрачную жизнь, покуражившись над экспонатами, но, вместе с тем, повторив знаковые ритуалы сакральной пушкинской биографии: от вакхических возлияний до дуэли.

Музейный экфрасис в чистом виде, без аллегорий и иносказаний, наличествует в романе в весьма дозированной форме. Кроме того, описание музейной экспозиции пропущено сквозь призму искаженного алкоголем восприятия героев, которые

плыли в этой тесной праздничной ночи [...] мимо остывших реликвий русского слова... Вот борода Толстого мелькнула из специального чехольчика, лязгнули садовые ножницы, которыми Чехов подстригал крыжовник Ионыча, застекленный, восстановленный Бунин, без вещей, был плоско размазан по стене (Битов 1990: 310).

Роман пропитан музейной темой, и определение собственно музейного экфрасиса здесь настолько же сложно, насколько сложно выделить в этом тексте Битова немузейный, свободный от музея дискурс. И тема вечного возвращения, и тема времени, и тема памяти, и тема личной истории - вплетаются в семантическую канву «романа-музея» слишком плотно, чтобы рассматриваться вне музейной парадигмы.

\section{Музейная тематика в современной русской прозе}

На рубеже XX-XXI веков музейный дискурс в русской прозе продолжает актуализироваться в контексте постмодернизма. Существенная составляющая музейной темы - коллекционирование предстает в современных текстах либо как абсурдная и бессмысленная деятельность, либо как навязчивая и маниакальная обсессия. В тексте Олега Постнова герой, наблюдавший в центре Петербурга за гигантской крысой, знакомится с «музеем крыс» 
в квартире некоего профессора Крона, но не находит в коллекции профессора особи, похожей на увиденное им животное. Экфрасис «музея», тем не менее, впечатляет разнообразием видов грызунов (Постнов 1997: 82). Неслучайно появление подобных текстов в эпоху музейного бума, когда открываются музеи с маргинальным контентом. «Интенция открывать музеи с самыми нелепыми экспонатами - „музей водки“, „музей кошек“ и пр., профанирует идею классического музея с артефактами, отобранными путем скрупулезного ценностного отбора. Если неважно, что хранить в музее, если любой пустяк может стать объектом, значит, и в классическом музее хранятся пустяки, культурный мусор» (КАлугинА 2001: 122). «Музей крыс» в тексте Олега Постнова - продукт как раз такой «мусорной культуры».

У петербургского писателя Сергея Носова в романе «Член общества или голодное время» феномен коллекционирования приобретает значение опасной мании: протагонист, пришедший в магазин старой книги, чтобы избавиться от ненужных изданий, попадает в общество коллекционеров-библиофилов, которые затем оказываются кулинарами, а потом - людоедами (Носов 2001). Столь абсурдная метаморфоза, обнажающая сомнительную суть коллекционирования в эпоху постмодерна, близка такому же пагубному преображению героя Джона Фаулза в романе «Коллекционер», увлекавшегося коллекционированием бабочек, а затем поймавшего жертву покрупнее - несчастную девушку, которую он заморил в неволе.

Но, возвращаясь к русской современной прозе, можно упомянуть в контексте обращения к теме собирательства образ безумного коллекционера в фантастическом мире будущего в романе Марины Бирюковой «Фамабрика». В эпоху, когда разрушен Эрмитаж, и никто не ценит подлинные древности, старый чудак собирает в туннеле заброшенного метро никому не нужную коллекцию вещей по принципу принадлежности «умершим людям». Тема смерти и бессмертия обыгрывается в романе в контексте музейной парадигмы. Главный герой романа Лотар участвует в реалити-шоу, главным призом в котором является вечная жизнь. Дорогу к цели указывают ключи, зашифрованные в символике разрушенного бывшего Петербурга. Время от времени Лотар повторяет про себя фрагменты экскурсии по Эрмитажу, которые чудом сохранились в замороженном мозгу экскурсовода, жившего в конце XX века. Лотар бережно хранит сведения о музее и считает себя его виртуальным хранителем. Для гида эта экскурсия была последней - на нее пришли странные посетители, которые начали портить экспонаты и в конце концов превратились в монстров.

Экфрасис музея в «Фамабрике» представлен в двух ипостасях. Это образ разрушенного несколько веков назад Эрмитажа, погребенного под слоем мусора и являющегося местом обитания йогов - черни, стоящей в мире будущего за гранью закона. И описание иного рода - Эрмитаж, сохранившийся в замороженном в прошлом мозгу экскурсовода, Эрмитаж как текст экскурсии, прерываемой странными репликами посетителей, оказавшихся пришельцами. 
Вот фрагмент описания Эрмитажа как обитаемой руины, в котором герой рассказывает об Иорданской лестнице Зимнего дворца:

Пройдя мимо Лаокоона, я опять оказался под мрачными, с отвалившейся лепниной, сводами... И вот! Она открылась, она была здесь. Барочная лестница с двумя беломраморными маршами, о которой говорил Иван. Ступени были так соразмерны моим шагам! Над головой мерцала золоченая лепнина, и осколки зеркал в ложных окнах тускло возвращали свет, - не из окон, которые были забиты фанерой и залеплены грязью, но из отверстия в крыше, где было видно небо - лазурно-голубое - на том месте, где когда-то был плафон с изображением Олимпа. Мои шаги гулко отдавались в вестибюле, куда я вернулся, не в силах более находиться на лестнице, поражающей воображение неестественной и пронзительной красотой, красотой в стадии распада (БирюковА 2016: 159).

И отрывочные фрагменты экскурсии, прерываемой абсурдными замечаниями странных посетителей, слишком озабоченных подлинностью экспонатов:

А-арп-чхи! А-арп!.. Вот (нрзб)! Спасибо. Отделка Павильонного зала носит черты эклектики. Это имитация стилей различных стран и эпох. Фуфло? Имитация! Работа Штакеншнейдера! Отсюда открывается прекрасный вид на Висячий сад. Нет, нельзя. Я сказал, нельзя! Четыре «фонтана слёз». Мозаика... вдвое уменьшенная копия с древнеримского оригинала. Подделка? Фуфло? Копия! Работа учеников Академии художеств! А вот и знаменитые Часы Павлин работы английского мастера Джеймса Кокса. Кокс, сё! Когда часы бьют, павлин распускает а... а... хвост, сова вращает глазами и крутит а... головой, петух а... а... кукарекает. Донт тач май баттон, плиз, сё! И вы... Ой! Ой!! Дама! Держите её! Вы разбили стекло! Что с ней? Она больна? Вызовите охрану! Вот эта... (нрзб)! Всё, мы уходим отсюда. Донт тач зе кок, плиз, сё! (БиРЮКовА 2016: 99).

Обретение связи с традицией мучительно для протагониста романа. Чтобы сохранить скудные сведения об Эрмитаже, он отказывается от вечной жизни. В романе музей разрушен и воспринимается как часть культурной парадигмы прошлого. Это, в определенном смысле, возвращение к риторике модернизма, но и признание ценности утерянной культуры в мире, полном симулякров.

\section{Заключение}

Символика музея в русской культуре XX века менялась в зависимости от соответствующего контекста: в период модернизма основной символической фигурой, ассоциировавшейся с классическим музеем, был «гроб» искусства, в эпоху постмодернизма музей, как и любой другой культурный феномен, подвергался гипотетической деконструкции по аналогии с текстом. Эти тенденции нашли отражение и в русской литературе. Музейный экфрасис 
у А. Иванова являет авангардистский дух отрицания музея, в романах К. Вагинова тот же дух модернизма диктует иронические коннотации в отношении основной музейной функции - коллекционирования, у Ю. Домбровского абсурдность музея связана с переживанием извращения культуры в сталинскую эпоху, а у С. Довлатова та же абсурдность обусловлена лицемерием, царящим в культурных институциях эпохи «застоя». У А. Битова символика «романа-музея» сосредоточена в области текста: гипертекстом представляется сам музей, так как даже биография героя строится по принципу экспозиции литературного музея, а собственно «музей-текст» подвергнут жесткой постмодернистской деконструкции.

Интертекстуальность музейного экфрасиса в прозе русских писателей XX века, несомненно, расширяет границы его толкования. Экфрасис музея может мыслиться не просто как описание музея и его экспонатов, но как комплекс литературных приемов, служащих цели создания соответствующего гипертекста. Развитие теории экфрасиса в последние десятилетия указывает на интерес научного сообщества к проблематике, связанной с определением функций и категорий взаимодействия слова и визуальных искусств, текста и образа. Исследование музейного экфрасиса представляется в этой связи перспективным направлением междисциплинарных исследований в сфере литературоведения, музеологии, философии и эстетики.

\section{Литература}

БАХТИн 1990 = БАХТИн М. М. Творчество Франсуа Рабле и народная культура средневековья и Ренессанса. Москва, 1990.

БирюковА 2016 = БирюковА Марина: Фамабрика. https://ridero.ru/books/famabrika/.

Битов 1990 = Битов Андрей: Пушкинский дом. Москва, 1990.

БОЧКАРЕВА 2014 = БОчКАРЕВА Н. С. (ред.) Экфрастические жанры в классической и современной литературе. Пермь, 2014.

ВАГИнов 2008 = ВАГИнов Константин: Козлиная песнь. Москва, 2008.

ВАГинов 2016 = ВАГИнов Константин: Гарпагониада. http://az.lib.ru/w/waginow_k_k/ text 0040.shtml.

ГЕЛЛЕР 1997 = ГЕЛЛЕР Леонид: На подступах к жанру экфрасиса. Русский фон для нерусских картин. Wiener Slawistischer Almanach. Sonderband 44. München, 1997. $151-171$.

ГЕЛЛЕР 2002 = ГЕЛЛЕР Леонид (ред.): Экфрасис в русской литературе. Труды Лозаннского симпозиума. Москва, 2002.

ГЕЛЛЕР 2013 = ГЕЛЛЕР Леонид: Экфрасис, или Обнажение приема. Несколько вопросов и тезис. В кн.: ТокАРЕВ Д. В. (ред.) «Невыразимо выразимое». Экфрасис и проблемы репрезентации визуального в художественном тексте. Москва, 2013. 44-60.

ГЕнис 1999 = Генис Александр: Пушкин у Довлатова. http://sergeidovlatov.com/books/ genis2.html.

ДовЛАтов 1991 = ДовЛАтов Сергей: Зона. Компромисс. Заповедник. Москва, 1991.

ДомьРОвский 2011 = ДомБРовский Юрий: Хранитель древностей. Москва, 2011.

Иванов 2003 = Иванов А. П. Стереоскоп. Санкт-Петербург, 2003. 
КАЛУГИНА 2001 = КАЛУГИНА Т. П. Художественный музей как феномен культуры. Санкт-Петербург, 2001.

Криворучко 2008 = Криворучко А. Ю. Экфрасис как модель искусства в произведениях И. А. Бунина, Б. А. Лавренева, В. А. Каверина. Известия РГПУ им. А. И. Гериена 33. Санкт-Петербург, 2008. 254-257.

Курицын 1996 = Курицын Вячеслав: Великие мифы и скромные деконструкиии. http:// magazines.russ.ru/october/1996/8/kurit.html.

МАЛЕВИч 1919 = МАЛЕВич Казимир: Ось цвета и объема. Изобразительное искусство. № 1. Петроград, 1919. 27-30.

МорОзОва 2006 = МоРОзОВА Н. Г. Экфрасис в прозе русского романтизма. Диссертация канд. филол. наук. Новосибирск, 2006.

Носов 2001 = Носов Сергей: Член общества или голодное время. Санкт-Петербург, 2001.

Постнов 1997 = Постнов Олег: Ночные повести Валерьяна Сомова. Нева 1997/10: 69-92.

Руьинс 2003 = Руьинс М. «Пластическая радость красотыл». Экфрасис в творчестве акмеистов и европейская традиция. Санкт-Петербург, 2003.

Солоухин 1966 = Солоухин В. А. Письма из Русского музея. http://lib.ru/PROZA/ SOLOUHIN/musej.txt.

ФЕДОРОв 1913 = ФЕДОРОв Николай: Музей, его смысл и назначение. В кн.: Философия общего дела. Статьи, мьсли и письма Николая Федоровича Федорова II. Москва, 1913. 398-473.

BARBetTy 2011 = BARBetTy C. Ekphrastic Medieval Visions. A New Discussion in Interarts Theory. New York, 2011.

CHeEke 2010 = CHeEke S. Writing for Art. The Aesthetics of Ekphrasis. Manchester, 2010.

Heffernan 2004 = HefFernan J. A. W. Museum of Words. The Poetics of Ekphrasis from Homer to Ashbery. Chicago, 2004.

KRIEGER 1992 = KRIEGER M. Ekphrasis. The Illusion of the Natural Sign. Baltimore-London, 1992.

LoIZEAux 1999 = LoizeAux E. B. Ekphrasis and Textual Consciousness. Word \& Image 15 (1999): 76-96.

SHAFFER 1998 = SHAFFER Diana: Ekphrasis and the Rhetoric of Viewing in Philostratus's Imaginary Museum. Philosophy \& Rhetoric 31 (1998): 303-316.

WeBB 1999 = WeBB R. Ekphrasis Ancient and Modern: the Invention of a Genre. Word \& Image 15 (1999): 7-18. 